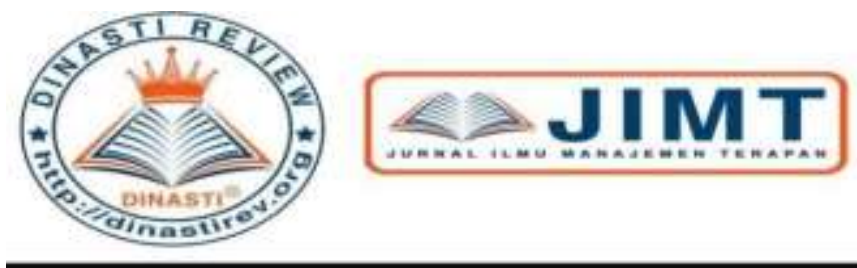

+62 878-9658-6407

087896586407

https://dinastirev.org/JIMT

editor@dinastirev.org

\title{
ANALISIS SWOT DALAM PENENTUAN STRATEGI BISNIS KAFE 165 UNIVERSITAS PUTRA INDONESIA YPTK PADANG
}

\author{
Rio Andhika Putra'), Ramdani Bayu Putra ${ }^{2)}$, Hasmaynelis Fitri ${ }^{3)}$ \\ 1) Mahasiswa Program Doktor Manajemen, Fakultas Ekonomi dan Bisnis, Universitas Putra Indonesia YPTK \\ Padang. \\ ${ }^{2)}$ Mahasiswa Program Doktor Manajemen, Fakultas Ekonomi dan Bisnis, Universitas Putra Indonesia YPTK \\ Padang. \\ ${ }^{3)}$ Fakultas Ekonomi dan Bisnis, Universitas Putra Indonesia YPTK Padang.
}

ARTICLE INFORMATION

Received: 15 April 2020

Revised: 22 April 2020

Issued: 4 Mei 2020

Corresponding author:

Rio Andhika Putra

E-mail:

rioandhikaputra@upiyptk.ac.id

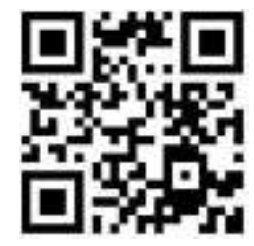

DOI:10.31933/JIMT
Abstract: Strategi bisnis adalah bagian penting yang harus dimiliki setiap pelaku usaha. Penelitian ini memcoba untuk menentukan strategi yang ideal melalui analisis SWOT. Objek penelitian ini adalah Kafe 165 yang merupakan unit Usaha dari Universitas Putra Indonesia YPTK Padang. Metode penelitian yang digunakan adalah metode deskriptif dengan teknik pengumpulan data melalui wawancara dan kuesioner kepada pihak-pihak atau stakeholder. Teknik Analisis SWOT meliputi IFE, EFE, CPM, TOWS, IE, SPACE, Grand Strategy dan QSPM. Temuan Matrik IFE dan matrik menunjukkan bahwa Kafe 165 memiliki ciri organisasi yang kuat secara internal dengan strategi yang dapat memanfaatkan faktor kekuatan yang mampu meminimalkan kelemahan dan mampu memanfaakan peluang dari acaman yang dihadapi. Hasil analisis Matriks TOWS, SPACE, IE, Grand Strategy sebagai hasil akhir penelitian ini merekomendasi strategi bisnis yang tepat bagi Kafe 165 adalah menerapkan strategi pengembangan pasar (market development) yang diikuti oleh pengembangan produk (product development) melalui inovasi yang berkelanjutan.

Keywords: Strategi Bisnis, SWOT, Inovasi.

\section{PENDAHULUAN}

Perkembangan teknologi informasi di era industry 4.0 telah memaksa setiap organisasi baik yang orientasinya profit atau non profit untuk berubah dan menyesuaikan kegiatan operasionalnya. Kondisi yang ini terjadi sebagai dampak dari perubahan lingkungan eksternal (perilaku konsumen, pesaing, inovasi dan teknologi), oleh karena itu semua entitas atau pihak-pihak yang melakukan kegiatan ekonomi harus mampu mengikuti perubahan tersebut. Agar semua organisasi dan pelaku ekonomi dapat menjalankan semua aktifitas dan dapat mencapai tujuannya, maka diperlukan suatu strategi bisnis yang tepat dan ideal untukt memberikan kekuatan dan kesenambungan organisasi dimasa yang akan datang. 
Rangkuti (2013), menyatakan strategi merupakan bagian dari perencanaan induk yang komprehensif, yang menjelaskan bagaimana perusahaan mencapai semua tujuan yang telah di tetapkan berdasarkan misi yang telah di tetapkan sebelumnya. Sementara kaitannya dengan strategi bisnis menurut Jatmiko (2004), strategi bisnis adalah serangkaian komitmen dan tindakan yang terintegrasi dan terkordinasi yang dirancang untuk menyediakan nilai bagi pelanggan dan dirancang untuk mendapatkan keunggulan kompetitif dengan mengeksplorasi kompetensi inti dari pasar produk tunggal atau produk individual dan spesifik.

Porter (1996), dalam Kuncoro (2010), mengatakan bahwa mengelola strategi sangat berbeda dengan mengelola operasi. Namun keduanya sangat penting, dan perlu diintegrasikan. Strategi visioner yang tidak dikaitkan dengan keunggulan proses operasi dan tata kelola (governance) tidak akan dapat diterapkan. Sebaliknya, keunggulan operasi mungkin bisa menurunkan biaya, memperbaiki mutu dan mengurangi jumlah proses dan waktu tunggu, tetapi tanpa visi dan panduan dari strategi, perusahaan tidak mungkin menikmati kesuksesan yang berkesinambungan hanya dengan perbaikan operasi semata (Kaplan \& Norton, 2008). Maka dari itu diperlukan strategi operasi dalam mengelola operasi bisnis agar tujuan yang telah ditetapkan dapat dicapai.

Kafe 165 adalah salah satu unit usaha yang berada di dalam lingkungan Universitas Putra Indonesia YPTK Padang yang telah berdiri semenjak tahun 2010 silam tahun yang lalu. Adapun kegiatan yang dijalani usaha ini adalah menyajikan makanan dengan berbagai rasa, mulai dari makan yang sederhana sampai makanan yang mengikuti selera atau pesanan dari pelanggan. Pelanggan dari Kafe 165 umumnya adalah mahasiswa dan para dosen yang berada pada lingkungan kampus dan sekitarnya. Namun juga tidak sedikit juga berasal dari luar kampus, takala ada kegiatan atau event tertentu yang melibatkan masyarakat atau pihakpihak lain yang datang ke dalam kampus. Pada saat kondisi itulah Kafe 165 mendapatkan kunjungan yang relatif besar namun pada kondisi-kondisi biasa Kafe ini hanya dikunjungi oleh mahasiswa atau para dosen yang ada di Kampus Universitas Putra Indonesia YPTK Padang. Beberapa upaya yang sudah dilakukan oleh pihak pengelola mulai dari mempersiapkan tempat yang nyaman dan sarana pendukung lain, seperti adanya Wifi, TV Kabel dan Sarana Foto Copy dan Print yang dapat mendukung tugas belajar dan mengajar mahasiswa dan dosen. Disamping itu berbagai menu makanan yang lengkap dengan harga yang terjangkau juga menjadi bagian dari pemasaran yang dilakukan oleh pihak pengelola. Namun berbagai keterbatasan yang dihadapi Pengelola adalah bahwa Kafe 165 hanya beroperasi pada siang hari saja sesuai dengan jadwal perkuliahan mahasiswa. Sedangkan pada waktu malam, liburan semester dan hari libur nasional, Kafe 165 tutup dan tidak melakukan aktifitas penjualan produknya. Selain itu, disekitar kampus juga terdapat pesaing atau usaha-usaha yang dilakukan oleh masyarakat yang memiliki aktifitas usaha yang relative sama dengan Kafe 165. Walaupun secara umum tingkat pertumbuhan usaha ini cenderung relatif stabil dengan peningkatan nilai penjualan dan pertumbuhan modal kerja dari tahun ketahun.

Melihat kondisi ini maka sudah seharusnya pihak pengelola untuk dapat menentukan Manajemen strategi yang baik, dalam memaksimalkan seluruh potensi yang dimiliki, baik itu berhubungan dengan faktor internal (kekuatan dan kelemahan) dan faktor eksternal (peluang dan ancaman) untuk memaksimalkan pencapaian tujuan dari organisasi. Menurut Ismail (2012), manajemen strategis merupakan serangkaian keputusan dan tindakan manajerial yang dihasilkan dari proses formulasi dan implementasi rencana dengan tujuan untuk mencapai 
keunggulan kompetitif. Dengan demikian dapat disimpulkan bahwa manajemen strategis merupakan perumusan dan implementasi tujuan utama dan inisiatif yang diambil oleh manajemen puncak organisasi atas nama pemilik, berdasarkan pertimbangan sumber daya dan penilaian lingkungan internal dan eksternal dalam menjalankan aktifitas operasinya.

Untuk itu Pengelola Kafe 165 harus mengetahui dan mengkokulasikan faktor internal (kekuatan dan kelemahan) dan faktor eksternal (peluang dan ancaman) untuk dapat melakukan perumusan strategi operasi yang tepat. Proses analisis, perumusan dan evaluasi strategi-strategi itu disebut perencanaan strategis. Adapun tujuan utama perencanaan strategis adalah agar perusahaan dapat melihat secara obyektif kondisi-kondisi internal dan eksternal, sehingga perusahaan dapat mengantisipasi perubahan lingkungan eksternal.

Penelitian terkait Analisis perumusan strategi dengan menggunakan analisis SWOT dengan Kafe sebagai objek penelitian sudah banyak dilakukan, seperti penelitian Julianti and Taswir (2019), Sholihah, Ali, Ahmed, and Prabandari (2016), Geereddy (2013), (Joshi \& Bansal, 2011) dan dan banyak lagi. Namun penelitian dengan objek Kafe yang berada di dalam Kampus masih relatif belum ada yang menelitinya dengan permasalahan dan kondisi sebagaimana yang telah dijelaskan di atas.

Berdasarkan masalah di atas, penulis ingin mengidentifikasi faktor internal (kekuatan dan kelemahan) dan faktor eksternal (peluang dan ancaman) Kafe 165 dan memformulasikan strategi bisnis yang tepat dan ideal yang dapat meningkatkan daya saing di masa mendatang.

\section{KAJIAN PUSTAKA}

Ismail (2012), strategi dipahami pula sebagai sebuah pola yang mencakup di dalamnya baik strategi yang direncanakan (intended strategy dan deliberate strategy) maupun strategi yang pada awalnya tidak dimaksudkan oleh perusahaan (emerging strategy) tetapi menjadi strategi yang dipertimbangkan bahkan dipilih oleh perusahaan untuk diimplementasikan (realized strategy). Lebih lanjut dikatakannya bahwa manajemen strategis merupakan serangkaian keputusan dan tindakan manajerial yang dihasilkan dari proses formulasi dan implementasi rencana dengan tujuan untuk mencapai keunggulan kompetitif, (Ismail, 2012).

Selanjutnya menurut David (2009), menyatakan bahwa perumusan proses manajemen strategis dapat dibagi atas tiga tahap, tahap pertama adalah perumusan strategi (strategic formulation), tahap kedua implementasi strategi (strategic implementation) dan tahap ketiga evaluasi strategi (strategic evaluation). Kegiatan Perumusan strategi meliputi pengembangan misi bisnis, mengenali peluang dan ancaman eksternal perusahaan, menetapkan kekuatan dan kelemahan internal, menetapkan tujuan jangka panjang, menghasilkan strategi alternatif, dan memilih strategi tertentu untuk dilaksanakan. Sedangkan kegiatan implementasi Strategi menetapkan obyektif tahunan, memperlengkapi dengan kebijakan, memotivasi karyawan, dan mengalokasikan sumber daya sehingga strategi yang dirumuskan dapat dilaksanakan; implementasi strategi termasuk mengembangkan budaya mendukung strategi, menciptakan struktur organisasi yang efektif, mengubah arah usaha pemasaran, menyiapkan anggaran, mengembangkan dan memanfaatkan sistem informasi, dan menghubungkan kompensasi karyawan dengan prestasi organisasi. Evaluasi Strategi adalah tahap akhir dalam manajemen strategis.

Prosedur yang ditempuh dalam penyusunan Rencana Strategis ini meliputi: metode pengumpulan data, analisis lingkungan eksternal (peluang dan ancaman) dan analisis lingkungan internal (kekuatan dan kelemahan). Hitt, Ireland, and Hoskisson (2012), 
menjelaskan peluang (opportunities) adalah gambaran kondisi-kondisi di dalam lingkungan umum yang dapat membantu organisasi mencapai daya saingnya. Ancaman (threats) merupakan kondisi-kondisi dalam lingkungan umum yang dapat mengganggu usaha organisasi dalam mencapai daya saing strategis. Komponen analisis eksternal terdiri dari: scanning, mengidentifikasi petunjuk awal dari perubahan dan kecenderungan lingkungan; monitoring, mendeteksi arti melalui observasi terus menerus atas perubahan dan kecenderungan lingkungan; forecasting, mengembangkan proyeksi atas hasil yang diantisipasi berdasarkan perubahan dan kecenderugan yang dimonitor; assessing, menentukan waktu dan pentingnya perubahan serta kecenderungan lingkungan untuk strategi organisasi dan manajemennya.

David (2009), menjelaskan bahwa teknik perumusan-strategi dapat diintegrasikan ke dalam kerangka kerja pengambilan keputusan tiga tahap yang terdiri dari tahap input, tahap pencocokan dan tahap keputusan. Tahap pertama, yaitu tahap input meringkas informasi dasar yang dibutuhkan untuk merumuskan strategi. Tahap kedua, yaitu tahap pencocokkan berfokus pada menciptakan alternatif strategi yang layak dengan mencocokkan faktor eksternal dan internal kunci. Tahap ketiga, yaitu tahap keputusan untuk mengevaluasi secara objektif alternatif-alternatif strategi yang layak dan dengan demikian, memberikan dasar tujuan untuk memilih strategi yang spesifik.

\section{METODE PENELITIAN}

Model penelitian ini adalah penelitian deskriptif yaitu penelitian yang mencoba untuk memecahkan masalah yang terjadi pada kondisi sekarang atau actual dengan pendekatanpendekatan analisis data hubungan sebab akibat. Objek penelitian ini adalah Kafe 165 yang berada pada lingkungan Kampus Universitas Putra Indonesia YPTK Padang. Pengumpulan data dilakukan melalui observasi, wawancara dan penyebaran kuesioner kepada pihak pengelola dan pihak-pihak lain yang secara tidak langsung juga memiliki hubungan dengan Kafe 165. Teknik analisis data dalam perumusan strategi bisnis ini menggunakan analisis SWOT (strengths, weaknesses, opportunities, threats).

Tahap 1 yaitu tahap input (input stage) disini aka ada Matriks Evaluasi Faktor Internal (Internal Factor Evaluation-IFE), Matriks Evaluasi Faktor Eksternal (External Factor Evaluation-EFE) dan Matriks Profil Persaingan (Competitive Profile Matrix-CPM). Sedangkan Tahap 2 yaitu Tahap Pencocokan (Matching Stage) meliputi penilaian Matriks Ancaman Peluang - Kelemahan - Kekuatan (Threats Opportunities Weakness-StrengthTOWS), Matriks Evaluasi Tindakan dan Posisi Strategi (Strategic Position and Action Evaluation-SPACE), Matriks Boston Consulting Group (BCG), Matriks Internal Eksternal (IE) dan Matriks Strategi Besar (Grand Strategy). Selanjutnya Tahap 3 adalah merupakan Tahap Keputusan (Decision Stage) berkaitan dengan Matriks Perencanaan Strategis Kuantitatif (Quantitative Strategic Planning Matrix-QSPM).

\section{HASIL DAN PEMBAHASAN}

Tahap pertama dalam analisis ini adalah penentuan bobot untuk masing-masing faktor internal (kekuatan (strengths) dan kelemahan (weaknesses) dan faktor eksternal (peluang (opportunities), dan ancaman (threats). Bobot untuk masing-masing faktor internal dan eksternal menggunakan skala signifikan dengan nilai $1=$ tidak signifikan, $2=$ Sedang, dan 3 
= Sangat signifikan. Setelah itu dihitung persentasi dari masing-masing bobot yang ada. Berikut hasil penilaian masing-masing factor internal dan eksternal :

Tabel 1. Pembobotan Faktor Internal- Eksternal

\begin{tabular}{|c|c|c|c|c|}
\hline No & Faktor-Faktor Internal & Bobot & Faktor-Faktor Eksternal & Bobot \\
\hline \multicolumn{3}{|c|}{ Kekuatan (Strength) } & \multicolumn{2}{|l|}{ Peluang (Opportunity) } \\
\hline 1 & $\begin{array}{l}\text { Berada didalam kampus yang dekat } \\
\text { dengan Mahasiswa dan tempat kos- } \\
\text { kosan mahasiswa }\end{array}$ & 0.105 & $\begin{array}{l}\text { Adanya dukungan Universitas dalam } \\
\text { pengembangan usaha }\end{array}$ & 0.111 \\
\hline 2 & $\begin{array}{l}\text { Penataan Tempat dan Sarana yang } \\
\text { nyaman }\end{array}$ & 0.053 & Terbukanya kerja sama dengan banyak pihak & 0.056 \\
\hline 3 & $\begin{array}{l}\text { Memiliki fasilitas WiFi serta TV kabel } \\
\text { (Indivision) dan fasilitas jasa print yang } \\
\text { mendukung tugas mahasiswa. }\end{array}$ & 0.053 & $\begin{array}{l}\text { Digemari anak muda atau mahasiswa yang } \\
\text { lebih suka nongkrong }\end{array}$ & 0.056 \\
\hline 4 & Menu lebih bervariasi dan lengkap & 0.105 & $\begin{array}{l}\text { Mudah dalam mendapatkan pemasok bahan } \\
\text { baku/dagangan }\end{array}$ & 0.056 \\
\hline \multicolumn{3}{|c|}{ Kelemahan (Weakness) } & \multicolumn{2}{|l|}{ Ancaman (Threat) } \\
\hline 1 & Pelanggan hanya mahasiswa semata & 0.158 & $\begin{array}{l}\text { Banyak pesaing dengan harga yang lebih } \\
\text { murah disekitar kampus }\end{array}$ & 0.222 \\
\hline 2 & $\begin{array}{l}\text { Kunjungan Pelanggan bergantung } \\
\text { dengan jadwal kuliah }\end{array}$ & 0.105 & \begin{tabular}{|l|} 
Saat liburan semester/hari libur kampus, \\
jumlah pengunjung akan berkurang secara
\end{tabular} & 0.167 \\
\hline 3 & $\begin{array}{l}\text { Jam operasional terbatas hanya siang } \\
\text { hari saja }\end{array}$ & 0.158 & $\begin{array}{l}\text { Adanya penjualan secara online dari pihak } \\
\text { lain }\end{array}$ & 0.167 \\
\hline 4 & Kurangnya tenaga pemasaran & 0.158 & $\begin{array}{l}\text { Mudah tumbuhnya pesaing yang baru untuk } \\
\text { membuka usaha disekitar }\end{array}$ & 0.167 \\
\hline \multirow[t]{2}{*}{5} & \begin{tabular}{|l|} 
Adanya aturan yang mengikat dari pihak \\
Universitas
\end{tabular} & 0.105 & & \\
\hline & Total & 1.000 & Total & 1.000 \\
\hline
\end{tabular}

Selanjutnya perhitungan dan penilaian matriks IFE dan matriks EFE menggunakan data dari hasil pembobotan dengan perhitungan skor berdasarkan kepentingan dari penilaian pihak pengelola Kafe diperoleh nilai skor untuk menghitung kedua matriks di atas. Berikut perhitungan kedua matriks IFE dan EFE pada tabel di bawah ini : 
Tabel 2. Matrik IFE dan Matrik EFE

\begin{tabular}{|c|c|c|c|c|c|c|c|c|c|}
\hline & Faktor-Faktor Internal & Bobot & Score & $\begin{array}{c}\text { Rata-rata } \\
\text { Tertimbang }\end{array}$ & & Faktor-Faktor Eksternal & Bobot & Score & $\begin{array}{c}\text { Rata-rata } \\
\text { Tertimbang }\end{array}$ \\
\hline \multicolumn{5}{|c|}{ Kekuatan (Strength) } & \multicolumn{5}{|c|}{ Peluang (Opportunity) } \\
\hline S1 & $\begin{array}{l}\text { Berada didalam kampus yang dekat } \\
\text { dengan Mahasiswa dan tempat kos. } \\
\text { kosan mahasiswa }\end{array}$ & 0.105 & 5 & 0.526 & 01 & $\begin{array}{l}\text { Adanya dukungan Universitas } \\
\text { dalam pengembangan usaha }\end{array}$ & 0.111 & 3 & 0.333 \\
\hline S2 & $\begin{array}{l}\text { Penataan Tempat dan Sarana yang } \\
\text { nyaman }\end{array}$ & 0.053 & 4 & 0.211 & 02 & $\begin{array}{l}\text { Terbukanya kerja sama dengan } \\
\text { banyak pihak }\end{array}$ & 0.056 & 3 & 0.167 \\
\hline $\mathrm{S} 3$ & $\begin{array}{l}\text { Memiliki fasilitas WiFi serta TV } \\
\text { kabel (Indivision) dan fasilitas jasa } \\
\text { print yang mendukung tugas } \\
\text { mahasiswa. }\end{array}$ & 0.053 & 3 & 0.158 & $\mathrm{O} 3$ & $\begin{array}{l}\text { Digemari anak muda atau mahasiswa } \\
\text { yang lebih suka nongkrong }\end{array}$ & 0.056 & 3 & 0.167 \\
\hline S4 & Menu lebih bervariasi dan lengkap & 0.105 & 5 & 0.526 & 04 & $\begin{array}{l}\text { Mudah dalam mendapatkan } \\
\text { pemasok bahan baku/dagangan }\end{array}$ & 0.056 & 3 & 0.167 \\
\hline \multicolumn{5}{|c|}{ Kelemahan (Weakness) } & \multicolumn{5}{|c|}{ Ancaman (Threat) } \\
\hline W1 & $\begin{array}{l}\text { Pelanggan hanya mahasiswa } \\
\text { semata }\end{array}$ & 0.158 & 2 & 0.316 & $\mathrm{~T} 1$ & $\begin{array}{l}\text { Banyak pesaing dengan harga yang } \\
\text { lebih murah disekitar kampus }\end{array}$ & 0.222 & 2.800 & 0.622 \\
\hline W2 & $\begin{array}{l}\text { Kunjungan Pelanggan bergantung } \\
\text { dengan jadwal kuliah }\end{array}$ & 0.105 & 2 & 0.211 & $\mathrm{~T} 2$ & $\begin{array}{l}\text { Saat liburan semester/hari libur } \\
\text { kampus, jumlah pengunjung akan } \\
\text { berkurang secara signifikan }\end{array}$ & 0.167 & 2.000 & 0.333 \\
\hline W3 & $\begin{array}{l}\text { Jam operasional terbatas hanya } \\
\text { siang hari saja }\end{array}$ & 0.158 & 2 & 0.316 & T3 & $\begin{array}{l}\text { Adanya penjualan secara online dari } \\
\text { pihak lain }\end{array}$ & 0.167 & 2.500 & 0.417 \\
\hline W4 & Kurangnya tenaga pemasaran & 0.158 & 2 & 0.316 & $\mathrm{~T} 4$ & $\begin{array}{l}\text { Mudah tumbuhnya pesaing yang } \\
\text { baru untuk membuka usaha disekitar } \\
\text { Kampus/Universitas }\end{array}$ & 0.167 & 2.800 & 0.467 \\
\hline W5 & $\begin{array}{l}\text { Adanya aturan yang mengikat dari } \\
\text { pihak Universitas }\end{array}$ & 0.105 & 2 & 0.211 & & & & & \\
\hline & Total & 1.000 & & 2.789 & & Total & 1.000 & & 2.672 \\
\hline
\end{tabular}

Berdasarkan tabel di atas, hasil perhitungan matriks IFE menemukan nilai faktor internal Kafe 165 sebesar 2,885. Sedangkan nilai hasil perhitungan matriks EFE untuk Kafe 165 sebesar 2,672. Menurut David (2009), berapapun banyaknya faktor yang dimasukkan dalam matriks IFE dan Matriks EFE, total nilai rata-rata tertimbang berkisar antara yang terendah 1,0 dan tertinggi 4,0, dengan rata-rata 2,5. Dalam artian organisasi yang memiliki nilai kedua matriks tersebut jauh di bawah 2,5 dipandang sebagai ciri organisasi yang lemah secara internal dan eksternal. Dengan demikan dapat diartikan bahwa Kafe 165 dengan nilai

di atas 2,5 menunjukkan ciri organisasi yang kuat secara internal yang artinya strategi perusahaan dapat memanfaatkan faktor kekuatan yang ada dan juga mampu meminimalkan

kelemahan berada di atas rata-rata. Sedangkan secara factor eksternal dengan nilai EFE di atas nilai rata-rata juga menunjukkan bahwa Kafe 165 juga dinyakini memiliki kemampuan memanfaakan peluang yang ada dari acaman yang dihadapinya dalam menjalankan usahanya.

Selanjutnya untuk mengetahui tingkat kompetitif Kafe 165 dengan industry atau usaha sejenis, untuk mengindikasi kekuatan dan kelemahan. Maka bagian ini akan melakukan perbandingan antara Kafe 165 dengan Kafe Kebab dan Debesto. Berikut analisis perbandingan dari ketiga unit usaha : 
Tabel 3. Matriks Profil Kompetitif (Competitive Profile Matrix-CPM)

\begin{tabular}{|c|c|c|c|c|c|c|c|c|}
\hline \multirow{2}{*}{ No } & \multirow{2}{*}{ Faktor Penentu Keberhasilan } & \multirow[b]{2}{*}{ Bobot } & \multicolumn{2}{|c|}{ KAFE 165} & \multicolumn{2}{|c|}{ KEBAB } & \multicolumn{2}{|c|}{ DEBESTO } \\
\hline & & & Peringkat & Nilai & Peringkat & Nilai & Peringkat & Nilai \\
\hline 1 & $\begin{array}{l}\text { Tempat dan Lokasi yang dekat } \\
\text { dengan Pelanggan/Mahasiswa }\end{array}$ & 0.231 & 3 & 0.692 & 3 & 0.692 & 3 & 0.692 \\
\hline 2 & $\begin{array}{l}\text { Tempat yang nyaman \& Fasilitas } \\
\text { Pendukung (WiFi serta TV kabel ( } \\
\text { Indivision ) jasa Foto Copy \& print } \\
\text { yang mendukung tugas } \\
\text { mahasiswa). }\end{array}$ & 0.231 & 3 & 0.692 & 2 & 0.462 & 2 & 0.462 \\
\hline 3 & Network yang luas & 0.154 & 3 & 0.462 & 3 & 0.462 & 2 & 0.308 \\
\hline 4 & Variasi Makanan yang lengkap & 0.231 & 3 & 0.692 & 2 & 0.462 & 2 & 0.462 \\
\hline 5 & Jumlah Pelanggan & 0.154 & 2 & 0.308 & 3 & 0.462 & 3 & 0.462 \\
\hline & Total & 1.000 & & 2.846 & & 2.538 & & 2.385 \\
\hline
\end{tabular}

Berdasarkan hasil matriks Competitive Profile Matrix-CPM di atas, diketahui bahwa posisi Kafe 165 berada di atas Kafe Kebab dan Debesto dengan total skor 2,846, sedangkan total skor untuk Kafe Kebab adalah 2,538 dan Debesto adalah 2,385. Hasil ini menunjukkan bahwa posisi atau daya saing Kafe 165 masih cukup baik bila dibandingkan dengan dua pesaing utamanya. Tahap selanjutnya adalah "tahap pencocokan", akan digunakan beberapa metode untuk menghasilkan strategi yang tepat untuk Kafe 165. Metode tersebut terdiri dari Matriks TOWS, Matriks SPACE, Matriks IE, dan Matriks Grand Strategy.

Berikutnya adalah matriks TOWS untuk menrumuskan strategi bisnis yang tepat bagi Kafe 165 :

\section{Tabel 4. Matriks TOWS}

\begin{tabular}{l} 
Internal \\
Eksternal \\
Peluang (Opportunity) \\
1. Adanya dukungan Universitas dalam \\
pengembangan usaha \\
2. Terbukanya kerja sama dengan \\
banyak pihak \\
3. Digemari anak muda atau mahasiswa \\
yang lebih suka nongkrong \\
4. Mudah dalam mendapatkan pemasok \\
bahan baku/dagangan \\
\hline Ancaman (Threat) \\
1. Banyak pesaing dengan harga yang \\
lebih murah disekitar kampus \\
2. Saat liburan semester/hari libur \\
kampus, jumlah pengunjung akan \\
berkurang secara signifikan \\
3. Adanya penjualan secara online dari \\
pihak lain \\
4. Mudah tumbuhnya pesaing yang \\
baru untuk membuka usaha disekitar \\
Kampus/Universitas
\end{tabular}

\section{Kekuatan (Strength)}

1. Berada didalam kampus yang dekat dengan Mahasiswa dan tempat koskosan mahasiswa

2. Penataan Tempat dan Sarana yang nyaman

3. Memiliki fasilitas WiFi serta TV kabel (Indivision) dan fasilitas jasa print yang mendukung tugas mahasiswa.

4. Menu lebih bervariasi dan lengkap

1. Memaksimalkan Peluang yang telah ada dengan Peningkatan Kapasitas Produksi dan menawarkan bentuk pelayanan yang lebih baik $(\mathrm{S} 4, \mathrm{O} 2, \mathrm{O} 3)$

Strategi Pengembangan Pasar

1. Penerapan harga yang lebih bersaing dengan memberikan potongan atau discount pada kondisi-kondisi tertentu (Paket Hemat) (A1,S1,S2, S3,S4)

2. Penerapann Teknologi untuk jangkauan daerah Pemasaran Produk dan layanan yang lebih luas (A3, S1,O1,O2,O3,O4) Strategi Pengembangan Produk

\section{Kelemahan (Weakness) \\ 1. Pelanggan hanya mahasiswa semata \\ 2. Kunjungan Pelanggan bergantung dengan jadwal kuliah \\ 3. Jam operasional terbatas hanya siang hari saja \\ 4. Kurangnya tenaga pemasaran \\ 5. Adanya aturan yang mengikat dari pihak Universitas \\ 1. Melakukan upaya peningkatan pasar yang lebih luas dengan jalan melakukan kerja sama dengan beberapa pihak tertentu (W1,W2, W3,O1,O2,O3)}

\section{Strategi Integrasi Horizontal}

1. Melakukan kerja sama dengan pesaing / perusahaan sejenis dan mensinergikan kekuatan yang dimiliki (A1 A2,A3,W1,W2, W3)

Strategi Integrasi Horizontal 
Hasil analisis matriks TOWS dapat diketahui bahwa ada empat strategi yang dapat dijalankan, yaitu strategi pengembangan pasar, strategi integrasi horizontal, strategi pengembangan produk, dan strategi penterasi pasar. Matriks SPACE dianalisis berdasarkan faktor kekuatan keuangan, kekuatan industri, stabilitas lingkungan dan keunggulan kompetitif. Analisis Matriks SPACE dapat dilihat pada Tabel 5.

Tabel 5. Matriks SPACE

\begin{tabular}{|c|c|c|}
\hline \multicolumn{2}{|r|}{ A. KEKUATAN KEUANGAN ((Finance Strength $/$ FS $)=$ Y } & \multirow{2}{*}{$\frac{\text { NILAI }}{4}$} \\
\hline 1 & $\begin{array}{l}\text { Pertumbuhan laba bersih meningkat } 5 \% \text { di tahun } 2019 \text { dibandingkan tahun } \\
\text { sebelumnya }\end{array}$ & \\
\hline \multirow[t]{2}{*}{2} & Pertumbuhan Asset Meningkat 5\% pada Tahun 2019 dibanding tahun sebelumnya & 4 \\
\hline & Total & 8 \\
\hline \multicolumn{2}{|r|}{ B. KEKUATAN INDUSTRI ((Industy Strength / IS) = X } & \\
\hline 1 & Potensi Pertumbuhan laba dengan usaha/Industri sejenis & 5 \\
\hline \multirow[t]{2}{*}{2} & Potensi Pertumbuhan & 3 \\
\hline & Total & 8 \\
\hline \multicolumn{2}{|r|}{ C. STABILITAS LINGKUNGAN (Environce Strength / ES) = Y } & \\
\hline 1 & Resiko bisnis & -3 \\
\hline \multirow[t]{2}{*}{2} & Tingkat inflasi yang cenderung naik & -2 \\
\hline & Total & -5 \\
\hline \multicolumn{2}{|r|}{ D. KEUNGGULAN KOMPETITIF (Competitivr Advantage / CA) = X } & \\
\hline 1 & Persaingan Harga & -1 \\
\hline 2 & Relasi dengan Pemasok & -1 \\
\hline \multirow[t]{2}{*}{3} & Pembayaran yang Fleksibel & -1 \\
\hline & Total & -3 \\
\hline \multicolumn{2}{|c|}{ KESIMPULAN } & \\
\hline \multicolumn{2}{|c|}{ Rata-rata ES adalah } & -2.5 \\
\hline \multicolumn{2}{|c|}{ Rata-rata CA adalah } & -1 \\
\hline \multicolumn{2}{|c|}{ Rata-rata IS adalah } & 4 \\
\hline \multicolumn{2}{|c|}{ Rata-rata FS adalah } & 4 \\
\hline \multicolumn{2}{|c|}{ Sumbu $\times(C A+I S)=$} & 3 \\
\hline \multicolumn{2}{|c|}{ Sumbu y $(\mathrm{ES}+\mathrm{FS})=$} & 2 \\
\hline
\end{tabular}

Setelah menentukan matriks SPACE untuk mengukur Kekuatan keuangan, Kekuatan industry, Kekuatan Lingkungan dan Kekuatan kompetitif, langkah selanjutnya adalah membentuk grafik Matriks SPACE untuk memetakan strategi yang cocok untuk Kafe 165. Berikut tampilan grafik Matriks SPACE : 


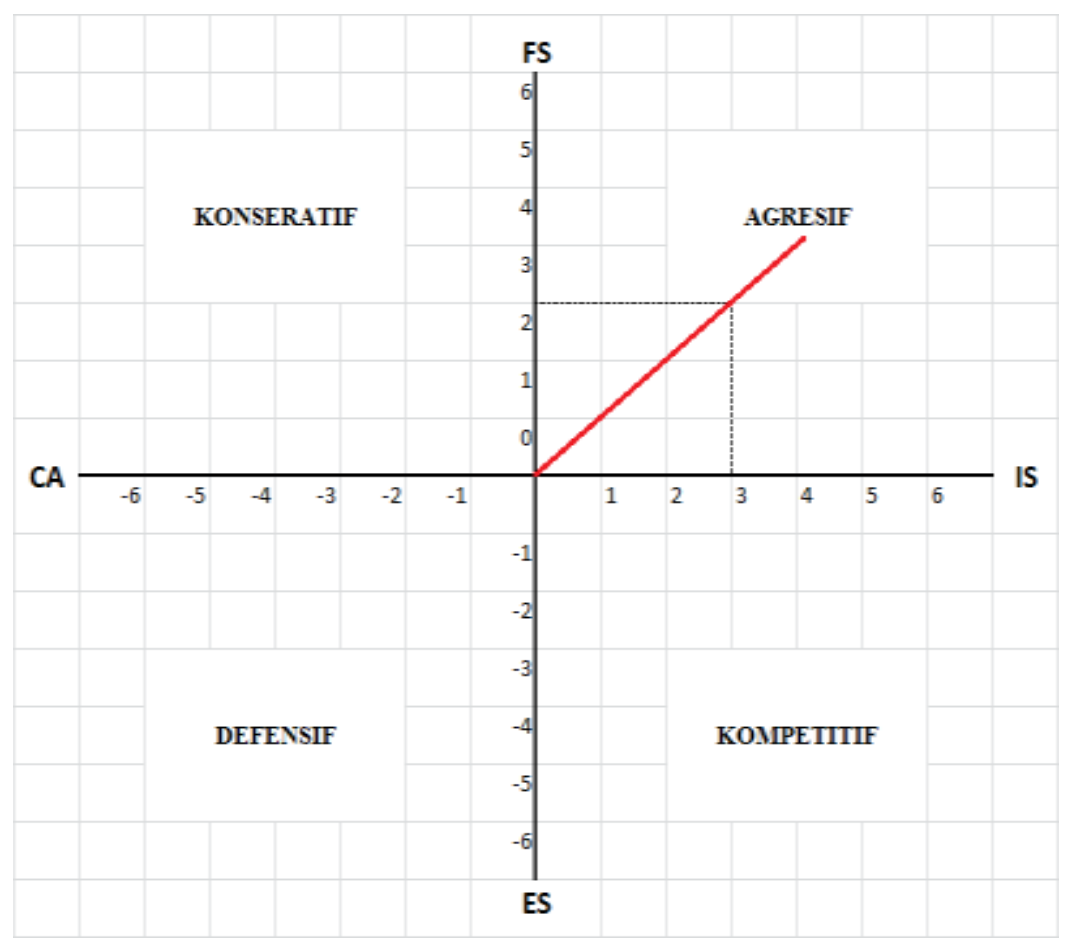

Gambar 1 Matriks Space

Berdasarkan hasil pengukuran Matrik SPACE pada Tabel 5 dan Gambar 1 Matrik SPACE Kafe 165 di atas, dapat ditentukan koordinat vektor arah pada kedua sumbu $\mathrm{x}$ sebesar 3, dan pada sumbu y sebesar 2. Sehingga dapat diketahui bahwa perusahaan berada pada kuadran I dengan Strategi Agresif. Kondisi ini juga menunjukkan bahwa perusahaan memiliki posisi yang baik untuk menggunakan kekuatan internalnya. Untuk itu beberapa strategi yang tepat dan cocok digunakan, antara lain: penetrasi pasar, pengembangan pasar, pengembangan produk, backward intergration, forward integration, horizontal integration, diversifikasi konglomerat, diversifikasi konsentrik, diversifikasi horizontal. Dilihat dari keadaan Kafe 165 maka, strategi yang bisa diterapkan yaitu penetrasi pasar, pengembangan produk, dan backward integration. Berikut ringkasan hasil analisis matriks internal eksternal pada Gambar 2 berikut :

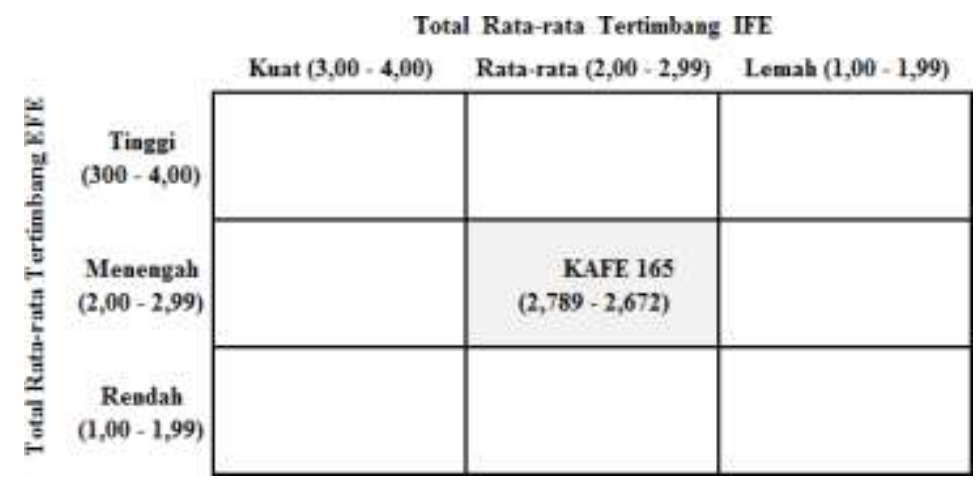

Gambar 2 Matriks Internal Eksternal 
Dari grafik di atas nilai matriks IFE 2,789 dan hasil EFE 2,672, dimana kedua nilai tersebut menunjukkan posisi Kafe 165 berada pada nilai sedang atau nilai rata-rata. Hasil matrik Intirnal-eksternal ini terletak pada Sel nomor 5, yang artinya sel ini mengambarkan posisi bertahan dan memelihara. Dengan kata lain Kafe 165 berada dalam pertumbuhan dan dapat dikelola dengan cara terbaik menggunakan strategi terjaga dan bertahan ; penetrasi pasar dan pengembangan produk adalah strategi yang umum digunakan untuk perusahaan yang masuk ke sel nomor V ini. Selanjutnya analisis perumusan strategi ini dilanjutkan pada penilaian Matriks Grand Strategy diuraikan pada Gambar 3.

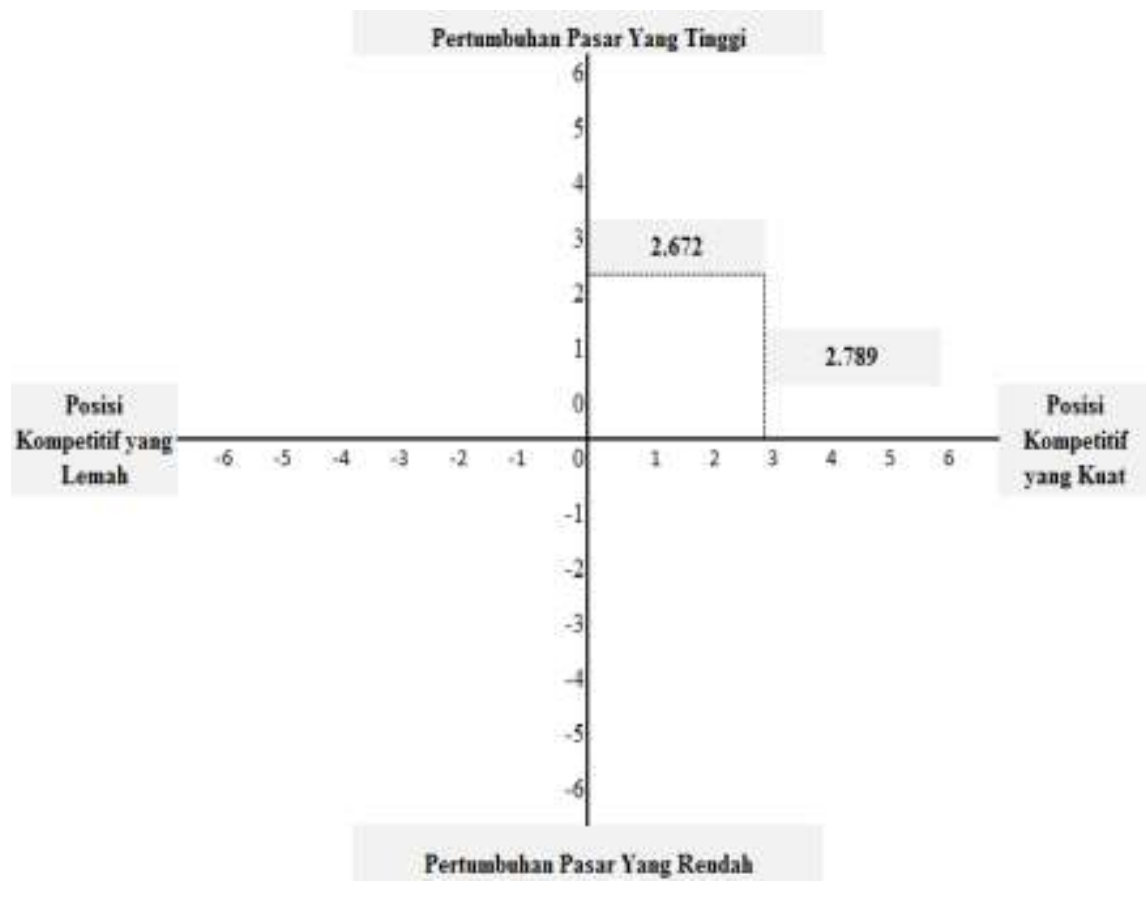

Gambar 3 Matriks Grand Strategy

Dari matriks grand Strategy pada Gambar 3, posisi Kafe 165 berada pada kuadran I. Dengan demikian maka beberapa pilihan strategi yang dapat diambil oleh perusahaan, yaitu penetrasi pasar, pengembangan pasar dan pengembangan produk. Perusahaan memiliki peluang dan kekuatan melalui pemanfaatan peluang yang ada dan mampu memanfaatkan peluang eksternal dalam banyak bidang.

Langkah terakhir dari analisis ini adalah membuat kesimpulan tentang alternatif strategi yang paling cocok untuk dijalankan oleh Kafe 165 untuk meningkatkan daya saingnya. Maka dapat untuk menilainya dapat dilakukan melalui matriks Quantitative Quantitative Strategic Planning Matrix (QSPM) dengan empat alternatif strategi yang dimasukkan, yaitu strategi pengembangan pasar, integrasi horizontal, pengembangan produk, dan penetrasi pasar. Keempat alternatif strategi tersebut selalu muncul dalam tahap pencocokkan. Berikut perhitungan dan penilaian matriks Quantitative Quantitative Strategic Planning Matrix (QSPM) : 
Tabel 6. Matriks QSPM-Faktor Internal

\begin{tabular}{|c|c|c|c|c|c|c|c|c|c|c|}
\hline \multirow{3}{*}{\multicolumn{2}{|c|}{ Faktor-Faktor Internal }} & \multirow{3}{*}{ Bobot } & \multicolumn{8}{|c|}{ Alternatif Strategi } \\
\hline & & & \multicolumn{2}{|c|}{ Penetrasi Pasar } & \multicolumn{2}{|c|}{$\begin{array}{l}\text { Pergembangan } \\
\text { Produk }\end{array}$} & \multicolumn{2}{|c|}{ Integrasi Horizontal } & \multicolumn{2}{|c|}{$\begin{array}{l}\text { Peagembangan } \\
\text { Pasar }\end{array}$} \\
\hline & & & NDT & TNDT & NDT & TNDT & NDT & TNDT & NDT & TNDT \\
\hline \$1 & $\begin{array}{l}\text { Berada didalam kampus yang } \\
\text { dekat dengan Mahasiswa dan } \\
\text { tempat kos-kosan mahasiswa }\end{array}$ & 0.105 & 2 & 0.211 & 3 & 0.316 & 2 & 0.211 & 4 & 0.421 \\
\hline$\$ 2$ & $\begin{array}{l}\text { Penataan Tempat dan Sarana yang } \\
\text { nyaman }\end{array}$ & 0.053 & 2 & 0.105 & 3 & 0.158 & 2 & 0.105 & 3 & 0.158 \\
\hline$\$ 3$ & $\begin{array}{l}\text { Memiliki fasilitas WFi serta TV } \\
\text { kabel (Indrision) dan fasilitas jasa } \\
\text { print yang mendukung tugas } \\
\text { mahasiswa. }\end{array}$ & 0.053 & 2 & 0.105 & 2 & 0.105 & 2 & 0.105 & 4 & 0.211 \\
\hline 54 & Menu lebith bervariasi dan lengkap & 0.105 & 2 & 0.211 & 3 & 0.316 & 2 & 0.211 & 4 & 0.421 \\
\hline \multicolumn{2}{|c|}{ Kelemahan (Weakntess) } & & & & & & & & & 0.000 \\
\hline W1 & $\begin{array}{l}\text { Pelanggan hanya mahasiswa } \\
\text { semata }\end{array}$ & 0.158 & 2 & 0.316 & 2 & 0.316 & 2 & 0.316 & 2 & 0.316 \\
\hline$w_{2}$ & $\begin{array}{l}\text { Kunjungan Pelanggan bergantung } \\
\text { dengan jadwal kufah }\end{array}$ & 0.105 & 2 & 0.211 & 2 & 0.211 & 1 & 0.105 & 2 & 0.211 \\
\hline W3 & $\begin{array}{l}\text { Iam operasional terbatas hanya } \\
\text { siang hari saja }\end{array}$ & 0.138 & 1 & 0.158 & 2 & 0.316 & 2 & 0.316 & 2 & 0.316 \\
\hline W4 & \begin{tabular}{|l|l} 
Kurangnya tenaga pemasaran \\
\end{tabular} & 0.158 & 1 & 0.158 & 1 & 0.158 & 2 & 0.316 & 1 & 0.158 \\
\hline \multirow[t]{2}{*}{ w5 } & $\begin{array}{l}\text { Adanya aturan yang mengikat deri } \\
\text { pihak Universitas }\end{array}$ & 0.105 & 2 & 0.211 & 2 & 0.211 & 2 & 0.211 & 2 & 0.211 \\
\hline & \begin{tabular}{|c|} 
Total \\
\end{tabular} & 1.000 & & 1.684 & & 2.105 & & 1.895 & & 2.421 \\
\hline
\end{tabular}

Tabel 7. Matriks QSPM-Faktor Eksternal

\begin{tabular}{|c|c|c|c|c|c|c|c|c|c|c|}
\hline \multirow{3}{*}{\multicolumn{2}{|c|}{ Faktor-Falktor Elksternal }} & \multirow{3}{*}{ Bobot } & \multicolumn{8}{|c|}{ Altematif Surateg } \\
\hline & & & \multicolumn{2}{|c|}{ Penetrasi Pasar } & \multicolumn{2}{|c|}{$\begin{array}{l}\text { Pengembangan } \\
\text { Produk }\end{array}$} & \multicolumn{2}{|c|}{ Integrasi Horizontal } & \multicolumn{2}{|c|}{$\begin{array}{c}\text { Pengembangan } \\
\text { Pasar }\end{array}$} \\
\hline & & & \multirow[t]{2}{*}{ NDT } & \multirow[b]{2}{*}{0.222} & \multirow{2}{*}{$\frac{\text { NDT }}{3}$} & \multirow{2}{*}{$\begin{array}{l}\text { TNDT } \\
0.333\end{array}$} & \multirow{2}{*}{\begin{tabular}{|c|} 
NDT \\
3 \\
\end{tabular}} & \multirow{2}{*}{\begin{tabular}{|l|} 
TNDT \\
0.333
\end{tabular}} & \multirow{2}{*}{$\frac{\text { NDT }}{4}$} & \multirow{2}{*}{$\frac{\text { TNDI }}{0.444}$} \\
\hline 01 & $\begin{array}{l}\text { Adanya dulangan Universtas } \\
\text { dalam pengembangan usaha }\end{array}$ & 0.111 & & & & & & & & \\
\hline $\mathrm{O} 2$ & $\begin{array}{l}\text { Terbukanya kerja sama dengan } \\
\text { banyak pilhak }\end{array}$ & 0.056 & 2 & 0.111 & 3 & 0.167 & 2 & 0.111 & 3 & 0.167 \\
\hline 03 & 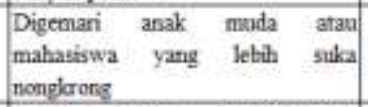 & 0.056 & 1 & 0.056 & 3 & 0.167 & 1 & 0.056 & 3 & 0.167 \\
\hline 04 & $\begin{array}{l}\text { Mudah delam mendapatkan } \\
\text { pemasok bahan baknd dagangan }\end{array}$ & 0.056 & 1 & 0.056 & 2 & 0.111 & 1 & 0.056 & 3 & 0.167 \\
\hline \multicolumn{11}{|c|}{ Ancaman (Threat) } \\
\hline II & $\begin{array}{l}\text { Banyak pesaing dengan harga yang } \\
\text { leth murah disekitar kampus }\end{array}$ & 0.222 & 2 & 0.444 & 2 & 0.444 & 2 & 0.444 & 2 & 0.444 \\
\hline $\mathrm{T} 2$ & $\begin{array}{l}\text { Saat liburan semester hari libur } \\
\text { kampus, jumlah pengunjung akan } \\
\text { bethirang secara significan }\end{array}$ & 0.167 & 1 & 0.167 & 1 & 0.167 & 1 & 0.167 & 2 & 0.333 \\
\hline$\tau 3$ & $\begin{array}{l}\text { Adanya penjualan secara online dari } \\
\text { pihak lain }\end{array}$ & 0.167 & 1 & 0.167 & 2 & 0.333 & 1 & 0.167 & 2 & 0.333 \\
\hline \multirow[t]{2}{*}{$\mathrm{T} 4$} & $\begin{array}{l}\text { Mudah tumbutrya pesaing baru } \\
\text { urntik membuka usaha disektar } \\
\text { Karnpos Universitas }\end{array}$ & 0.167 & 2 & 0.333 & 1 & 0.167 & 2 & 0.333 & 1 & 0.167 \\
\hline & \begin{tabular}{|c|} 
Total \\
\end{tabular} & 1.000 & & 1.556 & & 1.889 & & 1.667 & & 2.222 \\
\hline
\end{tabular}

\section{Tabel 8. Matriks QSPM Total Faktor Internal dan Eksternal}

\begin{tabular}{|c|c|c|c|c|}
\multirow{2}{*}{$\begin{array}{c}\text { Quantitative Strategic Planning } \\
\text { Matrix (QSPM) }\end{array}$} & \multicolumn{4}{|c|}{ Alternatif Strategi } \\
\cline { 2 - 5 } & Penetrasi Pasar & $\begin{array}{c}\text { Pengembangan } \\
\text { Produk }\end{array}$ & $\begin{array}{c}\text { Integrasi } \\
\text { Horizontal }\end{array}$ & $\begin{array}{c}\text { Pengembangan } \\
\text { Pasar }\end{array}$ \\
\hline Hasil QSPM Faktor Internal & 1.684 & 2.105 & 1.895 & 2.421 \\
\hline Hasil QSPM Faktor Eksternal & 1.556 & 1.889 & 1.667 & 2.222 \\
\hline Total & 3.240 & 3.994 & 3.561 & 4.643 \\
\hline
\end{tabular}

Berdasarkan matriks Quantitative Quantitative Strategic Planning Matrix (QSPM) internal dan eksternal di atas, dapat disimpulkan, bahwa dari empat alternatif strategi, jika diurutkan dari total nilai daya tarik terbesar, maka strategi pengembangan pasar adalah 
urutan teratas dengan total nilai daya tarik 4,643, lalu diikuti dengan strategi pengembangan produk dengan total nilai daya tarik 3,994, kemudian diikuti dengan strategi integrasi horizontal dengan total nilai daya tarik 3,561, dan urutan terakhir strategi penetrasi pasar dengan total nilai daya tarik 3,240 .

\section{KESIMPULAN DAN SARAN}

Berdasarkan hasil analisis SWOT (strengths, weaknesses, opportunities, threats) dalam perumusan strategi bisnis yang kompetitif Kafe 165 dapat disimpulkan, bahwa kekuatan kompetitif yang dimiliki dibandingkan dengan kompetiternya berdasarkan Matriks Profil Kompetitif (Competitive Profile Matrix-CPM), adalah lokasi yang dekat dengan pelanggan/mahasiswa, tempat yang nyaman dan dukungan fasilitas serta sarana pendukung mahasiswa dalam menjalankan aktifitas belajarnya dan menu makanan yang bervariasi dan lengkap.

Hasil perhitungan matriks IFE dan matriks EFE dengan nilai di atas rata-rata 2,5, juga menunjukkan bahwa Kafe 165 memiliki ciri organisasi yang kuat secara internal yang artinya strategi perusahaan dapat memanfaatkan faktor kekuatan yang ada dan juga mampu meminimalkan kelemahan yang dimilikinya. Selain itu Kafe 165 dapat dikatakan sebagai organisasi yang memiliki kemampuan yang dapat memanfaakan peluang yang ada dari acaman yang dihadapinya dalam menjalankan usahanya.

Selanjutnya hasil matriks TOWS, menginformasikan bahwa Kafe 165, disarankan memiliki strategi pengembangan pasar, strategi integrasi horizontal, strategi pengembangan produk, dan strategi penetrasi pasar. Sedangkan Matriks IE dan SPACE juga mengindikasikan agar Kafe 165 menerapkan strategi intensif, yakni strategi pengembangan produk, penetrasi atau pengembangan pasar dan integrasi horizontal. Selanjutnya analisis matriks Grand Startegy, memposisikan Kafe 165 pada kuadran I yang artinya usaha ini cenderung memiliki persaingan yang relatif kuat dan memiliki pertumbuhan pasar yang cepat.

\section{DAFTAR RUJUKAN}

David, F. R. (2009). Strategic Management: Manajemen Strategis Konsep. Jakarta [ID]. Penerbit Salemba Empat.

Geereddy, N. (2013). Strategic analysis of Starbucks corporation. Harward [Електронний ресурс].-Режим доступу: http://scholar. harvard. edu/files/nithingeereddy/files/starbucks_case_analysis. pdf.

Hitt, M. A., Ireland, R. D., \& Hoskisson, R. E. (2012). Strategic management cases: competitiveness and globalization: Cengage Learning.

Ismail, S. (2012). Manajemen Strategik. Jakarta: Erlangga.

Jatmiko, R. D. (2004). Pengantar Bisnis. Penerbit Universitas Muhammadiyah Malang. Joshi, M., \& Bansal, S. (2011). Café Coffee Day (CCD): A Case Analysis. Available at SSRN 1920827.

Julianti, N. D., \& Taswir, M. (2019). Analisis Swot Strategi Areom Kopi Di Tengah Trend "Ngopi" 2019 Ditinjau Dari Sudut Pandang Manajemen. Syntax, 1(7), 77.

Kaplan, R. S., \& Norton, D. P. (2008). The execution premium: Linking strategy to operations for competitive advantage: Harvard Business Press. 
Kuncoro, P. (2010). Strategi Komunikasi Divisi Pencitraan Lembaga Penyiaran Publik Radio Republik Indonesia Semarang dalam Membangun Citra Positif di Mata Masyarakat. Diponegoro University.

Porter, M. E. (1996). What is strategy? Harvard business review, 74(6), 61-78.

Rangkuti, F. (2013). Strategi promosi yang kreatif dan analisis kasus: Gramedia Pustaka Utama.

Sholihah, P. I., Ali, M., Ahmed, K., \& Prabandari, S. P. (2016). The Strategy of Starbucks and it's Effectiveness on its Operations in China, a SWOT Analysis. Asian Journal of Business and Management (ISSN: 2321-2802) Volume. 